\title{
Women, town councils, and the organisation of work in Bilbao and Antwerp: a north-south comparison (1400-1560)
}

\author{
Nena Vandeweerdt* \\ University of Leuven and University of Cantabria \\ ${ }^{*}$ Corresponding author. Email: nena.vandeweerdt@kuleuven.be
}

\begin{abstract}
In this article, I compare women's work opportunities in Bilbao, in northern Castile, and Antwerp, in the Low Countries, from 1400 to 1560. I argue that the different organisation of work in the two towns had a great influence on women's economic opportunities. Whereas women in Antwerp often worked alongside other members of their household because of the town's dominant craft guilds, Bilbao's informal trades were open to women on their own, independent of their husband or another male relative. As a result, women in Bilbao are more visible in the sources and were able to exert more influence on the town council.
\end{abstract}

\section{Introduction}

On 27 January 1438, a court in Antwerp, in the Southern Low Countries, sentenced six women to each make a short pilgrimage to the Our Lady of Hanswijk church in Mechelen, some $25 \mathrm{~km}$ to the south. The reason? The women had sold poultry illegally. Judges often imposed pilgrimages on those guilty of this type of offence in the Duchy of Brabant. ${ }^{1}$ Two days later, the six women submitted letters confirming that they had completed their pilgrimages. ${ }^{2}$ The type of illicit trade that resulted in these women being sentenced was common in all European pre-modern urban economies. ${ }^{3}$ In 1509, in the northern Castilian town of Bilbao, a group of female candle-makers had to appear before the town council. The council weighed the candles the women had been selling to determine whether their size complied with town regulations, suspecting that in order to increase their incomes the women had been making and selling candles that were smaller than the stipulated size and shoddily made. The council confiscated the sub-standard candles and imposed a fine of 100 maravedis on each woman; ${ }^{4}$ a considerable penalty, as the women only made 11 maravedís for each pound of candles they sold. ${ }^{5}$ The fines and forced pilgrimages are both examples of the punishments European town councils used as they tried to prevent illegal trade in the Late Middle Ages.

The two sources from Antwerp and Bilbao also offer useful information about women's involvement in the labour market in these two late medieval urban 
centres. In this article, I use them to consider the 'north-south thesis' - which argues that women in north-western Europe had more economic independence than women in southern Europe - through a fresh lens. I contend that the differences in the economic and social position of women in Bilbao and Antwerp were not so much due to their geographical locations, as historiography has often suggested, as to the different way the labour market was organised in the two towns. ${ }^{6}$ Using byelaws, the records of court cases, and tax registers I will show that employment in Antwerp was structured around craft guilds and women rarely had an economic identity outside of their family workshop. ${ }^{7}$ Furthermore, the activities of women working within the guilds were rarely questioned by the town council or the guild authorities, who were much more concerned about women working without oversight by the guilds. On the other hand, using similar sources, I will show that in Bilbao many women were able to make an independent living and to stand up to those opposing their interests. ${ }^{8}$ They brought cases to court and appeared before the town council on their own behalf. They even seem to have been able to influence the regulations which were passed. Nevertheless, this did not result in higher social and economic standing within the town. The economic position of women in Antwerp who worked as licensed or informal traders without being members of a guild seems to have been very similar to that of the market women of Bilbao. ${ }^{9}$

Historians have frequently argued that there was a difference in women's economic activities between northern and southern Europe - the so called 'northsouth' thesis. ${ }^{10}$ Explanations for the variation focus on several aspects of the two societies. First of all, there were the prevailing legal systems in the two regions. Roman law, which was used throughout southern Europe, placed more restrictions on women, as it made it more difficult for them to obtain property of their own. In northern Europe, on the other hand, where Roman law did not apply, women were permitted to inherit more property and married couples held property in common. This gave women, and widows in particular, greater economic agency and allowed them to set up their own businesses. ${ }^{11}$ Secondly, scholars point to the fact that in north-western Europe urban society was based on household production units; the economic importance of the nuclear family gave each household member, whether male or female, economic importance. In the European south, work in towns and cities were based more on extended family ties, which tended to constrain women's agency. ${ }^{12}$ A variety of other factors, such as the high level of urbanisation and high rates of women's literacy in northern Europe, have also been offered as explanations of the 'north-south thesis'. ${ }^{13}$

Although the thesis is widely accepted, it has often appeared in earlier studies as only a side note of research. ${ }^{14}$ Few studies have empirically compared women's economic agency using case studies from both the north and the south. ${ }^{15}$ Earlier studies may have identified differing levels of agency amongst women because they were comparing different contexts; considering women in rural versus urban communities, or of aristocratic versus artisan status, or in commercial versus industrial economies. ${ }^{16}$ Recently, criticism of the 'north-south thesis' has become more prevalent. Zucca Micheletto has questioned whether the cases studied in southern Europe were representative of the region. In her study of women of middling status in eighteenth-century Turin, she found that, as in north-western Europe, women in 
the town could be observed working in public spaces as a part of their household production unit and were found in most occupations. ${ }^{17}$ The generalisation that northern Europe was a single region has also been questioned. According to Kittell, most early comparative studies were based on Italy and England, even though rural English society differed greatly from the urbanized regions of northern Italy and the Low Countries. Furthermore, English women were subject to a different legal framework than women in the Low Countries. In addition, unlike the situation in north-western continental Europe, work in England was rarely organised by politically powerful craft guilds. ${ }^{18}$ Using England as a representative case study for northern Europe thus distorted any comparison between north and south. ${ }^{19}$ Finally, it has been argued that the 'restrictive' influence of Roman law on the women of southern Europe may not have been as strong as previously assumed and, as the law was a complex mixture of legal systems and local norms, it is unlikely to have had the same impact on women's socioeconomic position throughout the entire region. ${ }^{20}$ Dana Wessell Lightfoot has, for instance, shown that in fifteenth-century Valencia the dowry system, which has often been blamed for women's lack of financial independence, in fact promoted the active engagement of lower status and middling women in the town's economy. ${ }^{21}$

In order to test the 'north-south thesis' in this article I compare women's economic opportunities in two towns: Antwerp in the Low Countries and Bilbao in northern Spain, between 1400 and 1560. Rather than focussing on women's legal position, I consider the interaction between the town councils and female traders and labourers in the two towns, permitting a new perspective on differences in women's economic positions between north and south. The urban governments of the two towns had jurisdiction over urban law. In Antwerp, the 'Stadsmagistraat' was responsible for the daily governance of the town, and consisted of two mayors, sixteen aldermen, two treasurers, and a revenue officer. Since 1435, the 'Stadsmagistraat' was seconded by the 'Maandagse Raad', which was composed of the 'Stadsmagistraat' and twelve members of the craft guilds of Antwerp (I will refer from here on to both as town council or local government). ${ }^{22}$ In Bilbao, from ca. 1435 onwards, the only institution regulating daily life in the town was the town council of Bilbao. The council of Bilbao was smaller than that of Antwerp. Only 12-15 men, often coming from the same (merchant) families, were elected for the town council. ${ }^{23}$ Craftsmen did not have a political voice in the town council, which was mostly focussed on its commercial exploitations.

After introducing each town and the used sources in Section 2, in Section 3 I examine how town councils and economic organisations, such as the craft guilds, attempted to regulate women's work in the two regions. It is clear that there was an obvious distinction between the work women did within the overtly masculine craft guilds and the work they undertook within the informal economy. This section is based on ordinances from both towns, as they offer a comparable source base. In Section 4, I explore the reactions, both positive and negative, of women in Antwerp and Bilbao to the legal frameworks that the town councils tried to put in place. In Bilbao, women appear more often in the sources, either violating or trying to change town regulations. Citing evidence from court cases, I argue that women in Bilbao had more economic agency because there were no formal 
institutions organising their work. I define agency as an individual's potential to shape her own environment, following Sherry Ortner's definition that: '[...] "agency" is virtually synonymous with the forms of power people have at their disposal, their ability to act on their own behalf, influence other people and events, and maintain some kind of control in their own lives. ${ }^{24}$ Section 5 analyses gender inequality in Bilbao and Antwerp based on evidence from tax registers. The amounts paid by female and male taxpayers reveal gendered inequality in both towns. More interesting, however, is the wide gap revealed between the amount of tax paid by men and that paid by single and widowed women in Bilbao. Finally, Section 6 reviews the evidence from the two towns and argues the merits of such comparative analysis.

\section{Antwerp and Bilbao: commercial towns, different market institutions}

Antwerp and Bilbao were both important commercial hubs for their regions and despite their substantial political, socio-economic and cultural differences, there were crucial similarities between them. During the fifteenth century, Antwerp grew to be the commercial centre of the Duchy of Brabant and northern continental Europe in general. It held this position until it was overtaken by Amsterdam at the end of the sixteenth century. The main focus of Antwerp's economy was international commerce, organised by the town's merchant guilds. ${ }^{25}$ In addition, Antwerp's most productive and small-scale trade occupations were traditionally organised by craft guilds. Only citizens of Antwerp could become members of these privileged guilds, which held considerable power in the government of the town. ${ }^{26}$ People who failed to join a guild worked as wage workers or in informal forms of employment.

Bilbao's economy also increased significantly during the fifteenth and sixteenth centuries thanks to a rapid increase in migration to the town. ${ }^{27}$ Like most Castilian towns, Bilbao failed to match Antwerp in population numbers. However, its coastal location helped Bilbao successfully beat off competition from surrounding towns to become the Spanish Empire's most important port for the north Atlantic trade. ${ }^{28}$ Although the town's artisans and traders were not organised into formal trade institutions, as those in Antwerp were, the increase in commerce at the beginning of the sixteenth century did result in the formation of a merchant guild in Bilbao. The artisans of Bilbao never gained formal political influence over their town council, however. Some skilled occupations, such as shoemakers and tailors, were organised into craft associations, called brotherhoods or cofradías, but these principally pursued cultural and welfare objectives. ${ }^{29}$ Most occupations did not have a recognised institution setting boundaries on their activities. Instead, in theory each citizen of Bilbao was free to buy and sell goods within the local rules and regulations. ${ }^{30}$

Antwerp and Bilbao were both deeply involved in commerce and maritime trade, but the way in which work was organised within the two towns could not have been more different and had a profound impact on the labour opportunities of their female citizens. In Antwerp, craft guilds attempted to monopolize certain trades and production procedures and gain a formal role within the government of the town. Membership rules were exclusive and women were seldom permitted to enter crafts guilds in their own right. As Bert De Munck has stated, the privileged 
craft guilds drew their values from the idea that 'fathers, men and masters... formed the link between the city as an aggregation of economic households and the city as a body politic - or the larger household'; they were highly patriarchal. ${ }^{31}$ In Bilbao, the sources referring to the small number of brotherhoods do not mention any female workers or female family members of master craftsmen. Occupations in the town that were concerned with the processing of raw materials or inter-regional trade appear to have been exclusively masculine. Documents referring to particular guilds in neighbouring towns within the province of Biscay do mention the rights of guild members' widows while making it clear that members' spouses had cultural and religious obligations to the guild, but nothing similar exists in the records from Bilbao. $^{32}$ In contrast to the highly masculine guilds of Antwerp, the majority of trades in Bilbao supplying necessities were solely in the hands of women. Although these retailers were licenced and had permanent work, they were not formally organised. As a result, the town council often issued ordinances regulating their activities, and the records of many court cases survive which feature women in dispute with each other and with the local government. In contrast to the documents recording ordinances and court cases of Antwerp, in which women are seldom visible, the sources from Bilbao show female traders taking an active part in court cases but they contain little evidence of women working within a household-based economy.

Bakers offer an example of how the different organisation of work within Bilbao and Antwerp impacted on women's work and economic position. In Antwerp, the production and sales of bread were organised by the bakers' guild. Members paid a yearly fee to the guild, which was led by a Dean who was elected from amongst the master bakers, who were all male and ran their shop together with their wife, children, servants, and apprentices. Each member of the household would help to produce bread in their shop which they would then sell at the market and on the streets of Antwerp. Nevertheless, only the male master was ever visible in the records. $^{33}$ The bakers' guild faced competition from other inhabitants of Antwerp and its hinterland. The town held 'free market' days when everyone except guild members was allowed to sell bread, ${ }^{34}$ and during periods of scarcity, the town council allowed all citizens to sell bread. ${ }^{35}$ As the bakers' guild did not have a complete monopoly over the bread production and trade in Antwerp there were always illicit and informal sales, by individuals of both sexes, which were difficult for the town council and the craft guild to control. ${ }^{36}$ The bakers' guild was not alone; throughout the fifteenth and the sixteenth centuries informal competition was a recurring irritation for most craft guilds in Antwerp and the Low Countries. ${ }^{37}$ In Bilbao, the sources never mention 'free', i.e. non-guild, sales of bread, possibly because there were no guilds involved. Instead, the bread trade was organised by two occupational groups: the bread sellers (panaderas) and the bread bakers (horneras). The bread sellers prepared the dough and sold the finished bread. For safety reasons, however, local regulations prohibited citizens from possessing an oven in a private house. ${ }^{38}$ The panaderas therefore had to bring their dough to public ovens, where the horneras baked it for a fixed fee. These two occupations were completely in the hands of women, who also participated in the wheat trade. This was a very different picture from that in a number of towns in the southern Low Countries. In fourteenth-century Ghent, a town in the county of Flanders, the wheat trade was 
entirely in masculine hands and women were prohibited from buying or selling in the Corn Market. ${ }^{39}$ The town council in Mechelen, a town in Brabant, forbade the wives of wheat sellers to sell grain. ${ }^{40}$ There were no such restrictions in Bilbao.

The town ordinances from Antwerp and Bilbao make up a substantial body of comparative sources for the study period. They make it possible to contrast the rules and regulations each town council imposed on working women with actual, day-to-day practices. The sources also reveal the concerns that the town councils had when putting the regulations in place. ${ }^{41}$ The ordinances 'represent fairly ad hoc responses to existing economic and political contingencies'. ${ }^{42}$ The 'ad hoc responses' are sometimes made explicit by a narratio at the beginning of an ordinance. The documents from Bilbao contain particularly vivid descriptions of the daily practices that prompted the council to put regulation in place. Given that certain ordinances were issued repeatedly, it would appear that the citizens did not always obey the new rules, making it difficult for the town council to implement them effectively. ${ }^{43}$

The records of court cases and the sentence books from both Antwerp and Bilbao reveal just how far the expected norms and women's actual trading practices diverged. The Antwerp 'correction books', in which the town's courts recorded the sentences handed down to offenders, occasionally record market-related violations. In two correction books, running from 1414-1512 and 1513-1568 respectively, there are eleven sentences relating to women and their market activities. Other published registers contain a few judgements relating to women's employment passed by Antwerp's aldermen and town council. ${ }^{44}$ In Bilbao, court documents are provided by the town council and the Royal Chancellory of Valladolid (Real Chancillería de Valladolid), where disputes that could not, according to one of the parties involved, be settled impartially in the local courts were heard. Several tradeswomen involved in disputes with Bilbao's town council appealed to the Chancillería. The case reports give details of the women appearing, and are accompanied by records of the elaborate arguments and testimonies presented as well as of the evidence produced. A third source, tax registers, are available for both Bilbao and Antwerp. These allow a quantitative analysis comparing inequality between men and women in the two towns. They consist of a tax list from Bilbao in 1470, and, there are two lists from four districts (the 4th, 6th, 8th, and 11th) in Antwerp from 1537 and 1552. ${ }^{45}$ Analysis of these censuses of tax payers will cast further light on women's position in the labour markets of the two towns. As I will argue, the first two source types suggest that women in Bilbao had more independent agency. However, the 1470 tax list shows that the type of retailers appearing in the ordinances and court cases belonged to the town's lower classes. In Antwerp, by contrast, female taxpayers were more or less equally spread over all income categories. It seems that the predominance of a household-based economy, with its family production units, may have placed more restrictions on women and their trade activities but made their position in society more stable and secure.

\section{Byelaws and labour regulation: town councils and their concerns over working women's activities}

This section analyses the rules and regulations that the authorities in Bilbao and Antwerp imposed on working women. There was less regulation of women's 
work in Brabantine Antwerp than in Bilbao. In Antwerp the regulations varied according to a woman's marital status. In contrast, the legislation by the Bilbao town council relating to female retailers and tradeswomen made no reference to the women's marital status. The discussion in this section has two strands. First, I will consider the importance the authorities in each town placed on women's marital status when formulating legislation relating to women's work. Secondly, I will argue that women and their work are more visible in the sources when the occupations in which they were engaged were not organised by a craft guild. ${ }^{46}$ Moreover, it seems from the sources that women in such occupations possessed more agency.

In Antwerp, where most occupations were organised into craft guilds, the regulations relating to women's work treated single women, married women and widows differently. ${ }^{47}$ This focus on marital status stems from the dominance of household-based production in the economy of towns and cities in the Low Countries. $^{48}$ Daughters' work in their fathers' workshops went unrecorded. Wives were not often referred to in ordinances and court cases because it was assumed that husbands and wives worked as a team under the husband's name; ${ }^{49}$ the wife's work complemented that of her husband and was necessary to guarantee the family's income. Town councils seldom prohibited women from participating in the activities of their family's workshop, and as a result women and their contribution to their household's economy are seldom seen in the sources from Antwerp. Nevertheless, there is more regulation of women's work in the town's ordinances than might be expected. Both the town council and the local craft guilds had concerns about those women - and men - who did not work within a stable family production unit. ${ }^{50}$ In 1492, the Antwerp gardeners' guild complained to the town authorities that too many single women were joining their guild, despite the existence of an ordinance which stated that only married women could do so. ${ }^{51}$ After a hearing, the ordinance was reissued with an added provision stating that in the future, only gardeners' daughters whose parents were deceased could enter the guild. ${ }^{52}$ The guild clearly acknowledged the significance of the household-based economy, and the daughters of deceased gardeners were accepted as members because, as part of their parent's economic unit, they could already claim that privilege. ${ }^{53}$ Single women without such family ties could not join the guild. A dispute between groups of masters in the glove and purse makers' guild in 1474 also concerned women working in Antwerp's householdbased economy. The dispute centred on the female wage workers and apprentices that some of the masters employed. According to one group, 'any master can hire as many apprentices and women as he pleases, [... as long as they do not] do anything else than sewing and upholstering the said gloves or purses, which is women's work and women are supposed to do this. ${ }^{54}$ An opposing group argued that women were not permitted to work under the rules of the guild. The town council decided that the guild's master craftsmen could no longer hire female workers for a wage, apart from those who sewed together the two component parts of gloves. However, family members living with a master craftsman - his spouse, children and grandchildren could perform any task in the glove or purse making process. ${ }^{55}$ The town authorities and the craft guilds rarely restricted the work of women contributing to a family business. Even though the guilds were very male-centric this did not 
prevent members' immediate female relations from enjoying a stable, protected position. Some were even entitled to a number of the privileges held by full members of the guild. ${ }^{56}$ The women undertaking waged work for master glove and purse makers were, on the other hand, left without the protection of a formal organisation and had to find another way of making a living. They could not fall back on a recognised institution to provide an accepted context for their work. It was easier for the town council to prohibit the labour of women that did not work in such a context.

Scholars have often pointed to differences in family structure to explain the north-south dichotomy in the economic position of women, ${ }^{57}$ arguing that extended family ties in southern Europe limited women's agency. However, there is almost nothing in any of the sources from Bilbao, which refers to family structure in the context of women's work. When the town council placed regulations on women's work, they did not consider the women's marital status. The reason for this, I would argue, is that the lack of long-established craft guilds and the predominance of individual licensed traders in Bilbao meant that the town's tradeswomen were not as dependent on their husbands and male family members as those in Antwerp. Nevertheless the nuclear family was still favoured to a certain extent in Bilbao, as widows, sons and daughters were all able to inherit property. ${ }^{58}$ Among the four candle sellers mentioned in the introduction, one was married, one widowed and two single. ${ }^{59}$ Bilbao sources often feature appearances by groups of tradeswomen of varied marital status. On 2 October 1510, 19 female fishmongers delivered a petition to the town council, arguing against an ordinance that had been issued two weeks before. ${ }^{60}$ Before discussing their petition, let us consider how the women were identified in the records. The town council clerks referred to each of the 19 women by name and by their specific occupations within the fishmongers' trade. Three of them were identified as pescadoras: sellers of fresh fish. The other 16 were said to be sardineras: sellers of sardines and dried fish. ${ }^{61}$ None of them were identified by their relationship to a man. As none were said to be married, we are left wondering if they were all single women or whether the council did not attach any importance to the women's marital status in the context of their occupations. ${ }^{62}$ Two of the fishmongers mentioned in the petition, Catalina de Nafarra and María Pérez de Bermeo, appear again two years later in the record of a dispute brought before the Real Chancilleria de Valladolid. In the long report on this case there is no mention of the women's marital status and neither of them called on a male relative to represent her. ${ }^{63}$ In 1529 , another of the fishmongers appearing in the 1510 petition, Mayora de Iturribalçaga, was in dispute with the town council. Whereas the 1510 record did not mention whether she had a husband, in 1529 she is noted as being married to a citizen of Bilbao named Fernando de Agüero. Her marriage had not affected her position as a tradeswoman: the dispute arose from her work as a fishmonger, specifically her illicit selling of fresh fish even though she was registered as a sardinera. During the hearing, she presented the judges of the Sala de Vizcaya in the Real Chancilleria with a letter from her husband stating that she could act in court without him as her legal guardian. Marriage had not curtailed her sales activities nor, it seems, had it greatly reduced her independence. ${ }^{64}$ Thus it appears that, in contrast to the authorities in Antwerp, the town council in Bilbao did not take marital status into account when they passed 
regulations concerning the work of female traders. Moreover, many women seem to have worked on their own account, rather than with their husbands. The kind of household-based, guild-dominated economy that existed in Antwerp was not a feature of life in Bilbao, and the town council rarely considered the family as a production unit when taking decisions.

Although work was not formally organised by craft guilds in Bilbao, there seems to have been considerable distrust of working women; more than in Antwerp. If women working informally came to the attention of the town council, increased regulation usually followed. When the Antwerp authorities were dealing with women working in trades not organised by the guilds, the conditions they imposed on the women's work were actually quite similar to the regulations laid down in Bilbao. The aldermen of Antwerp passed several ordinances prohibiting women's work in informal trades. Scholars have often recognised the extensive activity of women in the informal economy. Bart Lambert, for example, states that nearly one-third of the people trading in Bruges' informal economy were women; many more than were members of the town's guilds. ${ }^{65}$ The uitdraagsters (second-hand itinerant traders) were one such group of female traders in Antwerp. ${ }^{66}$ They worked in parallel with the rag merchants' guild, which organised the buying and selling of used goods. ${ }^{67}$ Although women could be privileged members of this guild, there were only six women, five of them widows, among the 67 rag merchants on a sixteenth-century membership list. ${ }^{68}$ As well as rags, second hand dealers sold 'old clothes, old ironware, old linen, trifles, and other old stuff.' ${ }^{69}$ They probably sold these goods on behalf of merchants or other retailers in Antwerp and received a certain percentage for each piece sold. ${ }^{70}$ In Nuremberg and Amsterdam uitdraagsters seem to have practiced the second-hand trade on a larger scale. ${ }^{71}$ In Antwerp, where this type of trade was organised by the rag merchants' guild, the uitdraagsters seem to have traded on a smaller scale; they worked outside of any official craft guild but had to obtain a license, similar to those needed by Bilbao's female retailers. Every Antwerp uitdraagster had to swear an oath each year to the dean of the rag merchants' guild in order to continue her business. ${ }^{72}$ Even so Antwerp's town council and the rag merchants' guild kept strict control over the uitdraagsters, in the study period several ordinances were issued regulating their work. ${ }^{73}$ The town council was intent on setting boundaries on the amount of work the women could do and on the spaces where they could ply their trade, and was keen that they maintain their accountability to the rag merchants' guild. In one of the early regulations imposed by the council in 1436, it was stated that 'no second-hand dealer (could) have a shop' in the window of her home. ${ }^{74}$ This prevented uitdraagsters from developing a fixed site of business, even though they were licensed traders. As itinerant tradeswomen, the women did not work within family-run workshops where they could be overseen by their male kinfolk. Instead they worked on the margins of Antwerp's household-based economy, and for that reason their position was more contested and controlled.

Whereas the female-dominated second-hand goods trade was the exception in Antwerp, in Bilbao women were predominantly involved in the sale of almost every kind of provision. ${ }^{75}$ Regulation of these particular retail and marketing occupations was excessive. The town council of Bilbao dealt with the women in retail collectively, just as the town council in Antwerp had addressed the uitdraagsters 
as a single group. The case of the fishmongers reveals the attitude of Bilbao's town council. In Spanish and Portuguese towns, fish sales were mainly in the hands of women. ${ }^{76}$ Most of the female fishmongers sold small quantities of fish but some, and widows in particular, participated in the wholesale trade. ${ }^{77}$ Nevertheless, and despite being licensed traders, they were still subject to extensive regulation and male control. In 1512, the council added another layer of male control by appointing a male estimator. ${ }^{78}$ The Bilbao fishmongers experienced a process similar to that observed by Judith Bennett amongst English brewers: as certain positions within the trade became more lucrative, men moved into these higher status occupations. ${ }^{79}$ It was possible for entire trades to switch from being 'female' to 'male' in this way.

Between 1477 and 1515 Bilbao's town council issued more than 30 ordinances relating to the sale of fish, laying down rules on the quality, price, and weight of the fish the women fishmongers could sell. They also repeatedly passed regulations relating to market spaces, informal trade, and the organisation of the fish trade. More often than not, the ordinances were issued after existing regulations had been violated, or because the fish sellers had caused disorder or problems in the course of their activities. Because the women fishmongers were unregulated by an official trade organisation the town council kept them firmly in their sights.

Although their work was not organised by a male-led institution, the tradeswomen regularly tried to influence the regulation of their work that the town council promulgated. The absence of such institutions seems to have given them greater agency, rather than marginalizing their work. Bilbao's female fishmongers distributed one of the town's principal food sources to the population; a very important job. For this reason the town council regarded them with suspicion and even distain, believing that the women were in a position to sell the staple foodstuff for inflated, and sometimes extortionate, prices. ${ }^{80}$ The number of ordinances issued concerning the work of the fishmongers indicates that the town council tried to keep tight control over the selling of fish, but the Bilbao fishmongers were not a marginal group of illicit saleswomen trying to evade the council's control. Scholars have concluded that itinerant traders elsewhere in pre-modern Europe were organised and had stable market relationships at each stage of the retail process, and this was certainly true of Bilbao's fishmongers. ${ }^{81}$ Moreover, the fishmongers were able to exert some influence over the regulations imposed on their occupation by the town council. The ordinances were drawn up through a process of compromise, with all parties involved prepared to be flexible. When, in 1509, the Bilbao town council restricted the fishmonger's trade by fixing fish prices, they also guaranteed that only licensed fishmongers could sell fish. Furthermore the new regulations also specified that if merchants wanted to buy fish in wholesale, they had to allow the female fishmongers to buy up one-third of the wholesale stock at the same price. ${ }^{82}$ The council had to take into account the tradeswomen when regulating the fish trade, in this way giving the women agency to improve their sales opportunities. The following year, on 18 September 1510, the council banned the fishmongers from Bilbao's market square on the grounds that the smell from their fish was a blight on the marketplace. The fishmongers were instructed to open shops in the surrounding streets. ${ }^{83}$ Two weeks later, on 2 October, the 19 female fishmongers mentioned in the previous section submitted their petition to the council. They argued that as foreign merchants came to the market square 
specifically to buy fish, the fishmongers would lose income if these merchants could no longer find them. Furthermore, they argued, the smell of fish would be even worse in the town's narrow streets. The council revised its previous ordinance and set up a wooden shed in the market square in which the fishmongers could sell their fish. ${ }^{84}$ The fishmongers in Bilbao seem to have been 'a close-knit body, tightly bound together by a certain set of rights and privileges', much like female second-hand dealers (Keuflinnen) in early modern Nuremberg. ${ }^{85}$ Bilbao's tradeswomen were well aware of their rights and privileges and stood up for those rights themselves, as they had no organisation, such as a guild, to support and organise their work and look after their interests. ${ }^{86}$ As the lawsuit of Mayora the Iturribalçaga against the town council of Bilbao shows, this was harder to do if they did not cooperate as a group. Sentences against women individually were more effective than against the whole group of female retailers. ${ }^{87}$

In the sources relating to market activities in Antwerp, there are only rare hints that women were able to exert any type of direct influence on town council decisions. ${ }^{88}$ There are, however, some examples of women in predominantly female occupations bringing about changes in regulations in other towns in Brabant. In each of these cases, the occupation concerned was not organised by a guild. In 1424, for example, the Leuven spinners and combers, all of whom were women, conveyed a number of complaints about the regulations they were working under to the weavers' guild. The guild then took these complaints to the town council, asking for the regulations to be revised. ${ }^{89}$

I have argued throughout this section that the town council in Antwerp took a different approach to the regulation of female labour than did the council in Bilbao. Because work in Northern European towns was organised by craft guilds, women from these areas were less visible in the sources and their work opportunities depended on their marital status. In Bilbao, the predominantly female trades were highly regulated by the town council; a situation very similar to that of those female trades in Antwerp which were not overseen by a craft guild. Women retailers in Bilbao organised themselves in order to put pressure on the local government to bring about change. They had to act in this way, and we can observe them doing so, because they did not work as part of a male-dominated institution, which would have taken care of these problems for them.

\section{4. 'Trading offences' and councils' countermeasures}

In the previous section, it became clear that local governments found it more difficult to take effective action against women who were breaking existing regulations when the women stood up against them as a collective group. In court, a woman's arguments were greatly strengthened if she could emphasise that she was a member of a wider community and was not operating alone. The town councils of Antwerp and Bilbao could more easily restrict the market activities of individuals, male or female, than they could those of a group. ${ }^{90}$

In both towns, councillors were clearly concerned about where traders of both sexes conducted their business. Control over marketplaces affected the council's ability to control trade in general. ${ }^{91}$ In Antwerp, most trade took place in wellestablished locations. However, some traders, such as the rag merchants and female 
uitdraagsters, did not operate from a fixed location. As a result, the authorities found it more difficult to regulate these occupations. In 1485 the aldermen in Antwerp ordered the uitdraagsters to conduct their sales only on Fridays, from a clearly defined location in the central Market Square. ${ }^{92}$ Instead of placing an outright prohibition on the women's work, they placed limits on it by regulating where and when the women could trade. Sixty years later, a regulation applying to rag merchants and uitdraagsters in Antwerp stated that '[...] no one, no second-hand dealer, old cloth seller, cloth repairer or other person, whoever he is [...] can display, resell or sell in the Huidevettersstraat, Korte or Lange Gasthuisstraat, nor other places within this town $[\ldots] .{ }^{93}$ The traders concerned were apparently obstructing the main roads to the grain market, which was causing disputes and occasional fights. The town council decreed that from then on the rag merchants and uitdraagsters would only be able to sell their wares at Antwerp's northern gate, outside the commercial centre. ${ }^{94}$

The same preoccupation with control over where traders carried out their business is apparent in the mentioned ordinance and petition of the fishmongers in Bilbao in $1510 .^{95}$ The town council's need to control the traders' activities resulted in fines for those who did not sell their wares in the seven streets of Bilbao's inner town. ${ }^{96}$ The council was able to keep tighter control over all traders' market activities if they took place within the designated area. However, just as in Antwerp, not all trades were conducted in the town centre. A group of women called cojedoras worked on the outskirts of the town, guarding merchants' stocks of wheat while also completing sales of the grain. ${ }^{97}$ They collected the negotiated sums from the buyers, keeping a percentage for themselves and handing the remainder over to the merchants. According to the council, fraud and violations were rife in this business. Like the fishmongers, the cojedoras earned their income from the town's food supply and were therefore viewed with suspicion. ${ }^{98}$ The council decided in 1524 to make the occupation illegal. In a court case resulting from their decision, the council argued that the occupation had never been formally recognised and if some of (those involved) were cojedora or baratera before, it was only by the goodwill of the aforesaid council [...]. ${ }^{99}$ Their activities were harder to control than those of the fishmongers and other licensed retailers because they worked in locations spread throughout Bilbao. This was one reason why the council's reaction to the allegations of fraud and other offences occurring in this particular trade was so severe. The 1524 ordinance banning their occupation did not stop women from acting as cojedoras, however. ${ }^{100}$ In the decades that followed, disputes between cojedoras and the town council continued to be brought before the court of the Royal Chancellery.

In both Antwerp and Bilbao, the local governments were more concerned with trading locations and practices than with the identity and gender of the traders. The regulations they issued and the lawsuits they pursued reveal that they struggled to maintain control of the day to day practices of the traders. They had to repeat their rulings time and again, as the practices 'expected' by the regulations and those actually followed often diverged. ${ }^{101}$ Such divergence between 'norm' and 'practice' has been found by scholars elsewhere, and cases appear in sources from both Bilbao and Antwerp. ${ }^{102}$ It is clear that the town councils found it difficult to regulate the work of female traders. 
In both Antwerp and Bilbao, women's opposition to the institutions imposing restrictions on their economic activities was more effective when they were able to act collectively. When women in the two towns presented arguments in defence of their livelihoods, it was clearly of great importance that they could present themselves as working within a particular, recognisable group. In Antwerp, the sources rarely contain women's voices or their arguments relating to work. There are a few exceptions, however. In 1435, for example, the rag merchants brought a case against Liesbet Maes, the wife of Jan Godens, a tanner. Liesbet had belonged to the rag merchants' guild before marrying Jan, but the guild members were determined that she should leave the guild because she had married. This was not unusual, as several guilds did not allow women to continue as members once they married. ${ }^{103}$ Nevertheless, Antwerp's aldermen decided in favour of Liesbet and determined that she could remain in the guild on the condition that she could only ask her husband to help her transport her goods, he was not to help with her sales. ${ }^{104}$ Although Liesbet's economic opportunities were largely determined by her marital status, the Antwerp aldermen recognised the value of her guild membership, which endowed her with certain privileges and a status which seems to have outweighed as a married woman. Women like Liesbet, who were allowed into male guilds, were able to invoke the guilds' privileges to protect their position in the workplace. ${ }^{105}$ That individual women or groups of women could attach themselves to privileged organisations such as guilds became highly significant when they needed to justify their economic activities to their town council.

In Bilbao, women can be seen actively arguing their cases in the sources. They exhibit the same degree of agency in their court cases as they did in influencing the regulations governing their trades. The sources show neither the town council, nor women themselves referring to their marital status during legal arguments. Instead the women invoked their citizenship and other related privileges. As they did not belong to, or could not call upon, a privileged occupational organisation, they tried to claim membership of another community. ${ }^{106}$ When the cojedoras were forced to suspend their sales, for example, they argued that as citizens of Biscay province, they had the right to trade freely. Mayora de Iturribalçaga, one of the fishmongers in dispute with the town council in 1529, used the same argument. However, neither the council in Bilbao nor the higher court in Valladolid accepted this argument. The legal agreement that citizens of Biscay could trade freely clearly did not always affect daily practice. Without the safety net of a craft guild or association, tradeswomen in Bilbao were not in a strong legal position. Only by proving evidence of the utility of their work in court could they hope to influence the outcome of a case in their favour. One argument that proved effective in Bilbao was to claim poverty. In 1509, two linen cloth traders, Joana and Milia, appeared before the council, asking to be exempted from an ordinance the council had passed earlier. ${ }^{107}$ The two women sold linen beneath a scaffold on the outskirts of town, but the council had decreed that all linen sellers were to display their wares in one of the empty shops in the centre of Bilbao. Joana and Milia argued that they were too poor to pay the rent wanted for one of these shops. As an act of charity, the council extended the period that the two women could continue to sell their wares under the scaffold. ${ }^{108}$ 
The fact there were multiple court cases and that regulations had to be issued repeatedly both in Bilbao and, to a lesser extent, in Antwerp, shows that local governments found it difficult to make tradeswomen comply with the rules imposed on them. The women had to find ways to evade the restrictions because they needed to work; every opportunity to make money had to be taken or they would go without. ${ }^{109}$ It would appear that Bilbao's town council found it more difficult to control the town's tradeswomen than their counterparts in Antwerp; but that discrepancy might be related to the differences in the gendered division of wealth in the two towns.

\section{Economic inequality in Bilbao and Antwerp: a quantitative approach}

In this section I analyse tax registers to measure economic inequality in Antwerp and Bilbao. I argue that although women in Bilbao had a greater degree of agency than their counterparts in Antwerp, this did not necessarily mean that they enjoyed greater wealth. The tax registers of Bilbao and Antwerp detail the levies that the towns imposed on their citizens to help pay off the towns' debts. ${ }^{110}$ The tax registers of Antwerp contain the housing values of four of the town's districts in 1537 and 1552. All households had to contribute 10 per cent on house rent and real estate. The tax register of Bilbao from 1470 registers the tithe levies of both the seven main streets and the neighbourhoods outside of the city wall. The tax was calculated on the total value of the real estate and movable property per household. ${ }^{111}$ For both towns, the poorest households were exempt, although it is not known what percentage of the town population fell into this category. ${ }^{112}$ The type of data in the tax registers are limited. Only the location, the identification of the tax payers and tax amounts are given for all entries. Some entries, around 25 per cent in both towns, also mention the occupation of the tax payer. No information is available about the possible other members in the household, nor about the age of the tax payers. In Bilbao, around 23 of the female tax payers are identified by marital status. For men this is only around 1 per cent. In Antwerp, none of the men are identified by marital status, whereas almost 60 per cent of the women are.

Differences in the amounts of owed tax reveal inequality both between and within the sexes in both Antwerp and Bilbao. There is a striking contrast in the gender ratios amongst taxpayers in the two towns. Only 11.6 per cent of all registered taxpayers in Antwerp were women (see Table 1); in Bilbao the figure was 21.49 per cent (see Table 2). This contrast is not surprising; it mirrors the invisibility of women that we have seen in the other sources from Antwerp. There were fewer women registered as taxpayers in Antwerp because it was not necessary for them to be registered separately; they were taxed along with other members of their family production unit under the male head's name.

Of the 147 women registered as taxpayers in Antwerp, 85 (57.8 per cent) were widows (Table 1). Earlier studies have convincingly demonstrated that after the death of their husband widows in the Low Countries took over the running of their household and its economy, with the result that they often managed more resources than other women. Low Country widows also enjoyed favourable inheritance rights. ${ }^{113}$ The situation of the widows observed in the Antwerp tax registers from 1537 and 1552 agrees with these previous assessments, and their wealth 
Table 1. The number and percentage of tax payers by category, sex, and marital status, showing the median and average amounts of tax paid (in shillings) recorded in the 1537 and 1552 taxation lists, Antwerp

\begin{tabular}{|c|c|c|c|c|}
\hline \multirow[b]{2}{*}{ Category } & \multicolumn{4}{|c|}{ Antwerp } \\
\hline & $\begin{array}{c}\mathrm{N} \text { of } \\
\text { taxpayers }\end{array}$ & $\begin{array}{l}\% \text { of all } \\
\text { taxpayers }\end{array}$ & $\begin{array}{l}\text { Median amount of } \\
\text { tax paid (shillings) }\end{array}$ & $\begin{array}{l}\text { Average amount of } \\
\text { tax paid (shillings) }\end{array}$ \\
\hline Heirs & 4 & 0.3 & 211.2 & 630.6 \\
\hline Men & 1115 & 87.9 & 115 & 188.2 \\
\hline \multicolumn{5}{|l|}{ Not stated } \\
\hline \multicolumn{5}{|l|}{ Married } \\
\hline Married couple & 1 & 0.1 & 20 & 20 \\
\hline Other & 1 & 0.1 & 20 & 20 \\
\hline Women & 147 & 11.6 & 55 & 136 \\
\hline Not stated & 60 & 4.7 & 25 & 73.2 \\
\hline Married & 1 & 0.1 & 170 & 170 \\
\hline Single & 1 & 0.1 & 80 & 80 \\
\hline Widow & 85 & 6.7 & 112.5 & 180 \\
\hline Widow and heirs & 1 & 0.1 & 500 & 500 \\
\hline Total & 1269 & 100 & 110 & 183.60 \\
\hline
\end{tabular}

Source: City Archives of Antwerp, Antwerp (hereafter CAA), HN\#103, Belastingscohieren van 1537. Huizentelling: 4de en 6de wijk, buitenijen (PK 2559 en 2566), 1537; CAA, HN\#579, Afschriften uit RK 2387 en RK 2523, 1552.

Note: The 1537 and 1552 taxation lists covered only the 4th, 6th, 8th and 11th district of Antwerp.

elevates the median amount paid by women taxpayers. The median housing value in 1537 and 1552 of women who were single or whose marital status was not known was 52.5 shillings; widows' houses valued a median of 112.5 shillings. The median housing value of male-headed households was 115 shillings. Women who appeared in the register on their own but were not heads of their deceased husband's household probably found it harder to make sufficient income to earn a decent living and this is reflected in the amount of tax they had to pay. In addition, because they were not part of family production unit they did not always have access to the privileged occupations many gilded families enjoyed. Married women are almost completely absent from the Antwerp tax registers; their husbands are listed as paying the taxes. ${ }^{114}$

Of the 147 women listed in the registers, only three were given occupational titles: a midwife, a pastry seller and a seamstress. These three women's housing values was a median of 120 shillings tax, 10 schillings more than the average taxpayer and an amount equal to that paid by the 316 male taxpayers whose occupations were listed (see Table 3). Although 120 shillings is probably representative of the taxes paid by the middling classes and craftsmen in Antwerp, we know the occupations of too few women to be able to make a general statement about the impact of women's occupation branches on their wealth. 
Table 2. The number and percentage of tax payers by category, sex, and marital status, showing the median and average amounts of tax paid (in maradevís) recorded in the 1470 taxation register, Bilbao

\begin{tabular}{|c|c|c|c|c|}
\hline \multirow[b]{2}{*}{ Category } & \multicolumn{4}{|c|}{ Bilbao } \\
\hline & $\begin{array}{c}\mathrm{N} \text { of } \\
\text { taxpayers }\end{array}$ & $\begin{array}{l}\% \text { of all } \\
\text { taxpayers }\end{array}$ & $\begin{array}{l}\text { Median amount } \\
\text { of tax paid } \\
\text { (maravedis) }\end{array}$ & $\begin{array}{c}\text { Average amount } \\
\text { of tax paid } \\
\text { (maravedis) }\end{array}$ \\
\hline Heirs & 121 & 5.8 & 169 & 432.9 \\
\hline Men & 1320 & 63.6 & 187 & 615.9 \\
\hline Not stated & 1309 & 63.1 & 187 & 619.7 \\
\hline Married & 11 & 0.5 & 125 & 160.7 \\
\hline Married couple & 17 & 0.8 & 62 & 62 \\
\hline Other & 3 & 0.1 & 31 & 31 \\
\hline Women & 446 & 21.5 & 31 & 83.4 \\
\hline Not stated & 344 & 16.6 & 31 & 84.2 \\
\hline Married & 35 & 1.7 & 62 & 118.5 \\
\hline Single & 36 & 1.7 & 31 & 42.4 \\
\hline Widow & 31 & 1.5 & 62 & 82.6 \\
\hline Widow and heirs & 168 & 8.1 & 293 & 723.2 \\
\hline Total & 2075 & 100 & 156 & 494.4 \\
\hline
\end{tabular}

Source: Enríquez Fernández, Hidalgo de Cisneros Amestoy, Lorente Ruigómez and Martínez Lahidalga, Repartimientos y foguera-vecindario.

Note: The 1470 tax register covered Bilbao and its outer neighbourhoods.

In Bilbao in 1470, 446 ( 21.5 per cent) of the 2075 registered taxpayers were women and 31 of those ( 7 per cent of all women) were widows (Table 2). Widows and other women paid lower rates of tax than men. Men paid 187 maravedís on average, while women paid, 31 maravedís. Widows in Bilbao paid a median amount of 62 maravedis, higher than the median for all women, but still far below that of male taxpayers. Moreover, the great majority of widows listed in the Bilbao tax registers belonged to the five lowest deciles of taxpayers; they were not as fortunate as widows in Antwerp (see Figure 1). They were vulnerable both socially and economically, as has also been shown to be the case for widows in Barcelona. ${ }^{115}$ Earlier studies of the Biscay province argued that widows and single women from low and middling classes were probably economically active because they needed the income. ${ }^{116}$ Some of those listed in the tax registers were undoubtedly amongst the retailers and tradeswomen referred to in the ordinances and the court cases. However, in the 1470 tax list of Bilbao a further 168 widows were listed together with their husband's heirs. These widows were not considered independent legal parties but were grouped together with the heirs, for unclear reasons, so they cannot be treated as 'women' in the calculations. Those in the 'widow and heirs' category paid a median tax amount of 293 maravedis, which exceeds the median amount paid by male taxpayers. Clearly not all widows in Bilbao lived in 
Table 3. The number and percentage of male taxpayers with occupation references, showing the median amount of tax paid (in shillings) recorded in the 1537 and 1552 taxation lists, Antwerp

\begin{tabular}{lccc}
\hline & \multicolumn{3}{c}{ Antwerp } \\
\cline { 2 - 4 } & $\begin{array}{c}\text { N of male tax } \\
\text { payers }\end{array}$ & $\begin{array}{c}\text { \% of all male tax } \\
\text { payers }\end{array}$ & $\begin{array}{c}\text { Median amount of male tax } \\
\text { paid(s) }\end{array}$ \\
\hline Not stated & 799 & 71.7 & 110 \\
\hline Other & 316 & 28.3 & 120 \\
\hline Total & 1115 & 100.0 & 115 \\
\hline
\end{tabular}

Source: See Table 1.

poverty. Only once a married couple's possessions had been divided between the heirs and the widow, and the widow's possessions were assessed on their own, did the disparity in taxable property held by widows and by male taxpayers appear. Furthermore, the inequality between younger and older widows that Mireia Comas-Via found in Barcelona may also have been a factor in Bilbao, but the 1470 tax register does not provide conclusive evidence of this. ${ }^{117}$ Single women and women whose marital status was not given in the 1470 register paid the lowest amounts of tax on the entire list. Some of them can be traced back to the hearth census of 1492, showing that they were women living together with others who were less well off. ${ }^{118}$ Nevertheless, as in Antwerp, most married women were invisible in the Bilbao registers because they were not taxpaying heads of household.

In contrast to Antwerp's tax records, the occupations of many of the women listed in the Bilbao tax census were given (Table 4). The types of occupations listed reflect the economy of the town. The 23 seamstresses and 12 servants worked in occupations that employed many women in pre-modern European towns. Women with occupations familiar from the other sources, such as the fishmongers, bread sellers, and fruit sellers, are recorded. Most of the women listed, including those whose occupation is given, paid 31 maravedis in tax; they did not belong to the highest social groups, and their incomes were far below that of the average man. ${ }^{119}$ Yet this does not mean that working women in Bilbao all lived in poverty. Although they had to work for a living, the fact that some could afford to pursue court cases at the Royal Chancellery in Valladolid shows that there were tradeswomen who possessed some capital.

If we divide the taxpayers listed in each town's tax registers into deciles of equal numbers of tax payers per decile (207 per decile for Bilbao, 124 per decile for Antwerp), it becomes clear that more taxpaying women in Bilbao belonged to the lowest economic groups of society than was true in Antwerp. The division in equal groups of tax payers allows for a comparison of the wealth distribution per gender in the two towns, as it evens out the different monetary values. Not all tax payer categories, as can be found in Table 1 (for Antwerp) and Table 2 (for Bilbao), are included in this calculation. As this section scrutinised economic inequality based on gender, only the categories 'men' and 'women' are included (Figure 1). 
Table 4. The number and percentage of female taxpayers, by reported occupation showing the median amount of tax paid (in maravedís) recorded in the 1470 tax registers, Bilbao

\begin{tabular}{lccc}
\hline & \multicolumn{2}{c}{ Bilbao } \\
\cline { 2 - 4 } Occupations & $\begin{array}{c}\text { N of female } \\
\text { taxpayers }\end{array}$ & $\begin{array}{c}\text { \% of all female } \\
\text { taxpayers }\end{array}$ & $\begin{array}{c}\text { Median amount of female tax } \\
\text { paid (maravedís) }\end{array}$ \\
\hline Not stated & 366 & 82.1 & 31.0 \\
\hline Bread seller & 5 & 1.1 & 33.0 \\
\hline Fruit seller & 3 & 0.7 & 31.0 \\
\hline Housekeeper & 15 & 3.4 & 31.0 \\
\hline Laundress & 6 & 1.3 & 46.5 \\
\hline Linen seller & 2 & 0.4 & 125.0 \\
\hline Retailer & 11 & 2.5 & 31.0 \\
\hline Sardine seller & 2 & 0.4 & 31.0 \\
\hline Seamstress & 23 & 5.2 & 31.0 \\
\hline Servant & 12 & 2.7 & 31.0 \\
\hline Shopkeeper & 1 & 0.2 & 62.0 \\
\hline Total & 446 & 100 & 31.0 \\
\hline Source & & & \\
\hline
\end{tabular}

Source: See Table 2.

Sixty-seven per cent of the taxpayers in the Bilbao's lowest two deciles were women (see Table 5). This is particularly striking because of the high ratio of male to female taxpayers on the list. Since all of the women listed as retailers and small-scale tradeswomen fell into the two lowest deciles, they were among the town's poorest taxpaying residents. In Antwerp, although the percentage of women in the lowest two deciles increased in comparison with the higher ones, they still counted for only 21.6 per cent of the tax payers in these deciles. There was clearly inequality based on gender in both towns. Figure 1 shows that the proportion of female taxpayers was highest in the lowest deciles in both Bilbao and Antwerp. Nevertheless, the extent of the inequality between men and women was clearly greater in Bilbao.

As I have argued in this article, the greater visibility and agency of women in Bilbao did not put them in a stronger financial position. Over the last few decades the impact of economic institutions, such as craft guilds, has been the topic of various studies. ${ }^{120}$ Scholars have argued that the exclusion of women from the formal market, a consequence from the organisation of labour in guilds, slowed economic growth. ${ }^{121}$ Although conclusions about general growth in the wider economies of Bilbao and Antwerp cannot be made based on the two tax lists, the tax registers make it clear that the independent tradeswomen in Bilbao did not enjoy a higher socio-economic position. In Antwerp, female taxpayers were more evenly distributed across all tax brackets. As women from middling groups usually belonged to a family production unit, this may be why the percentages of female taxpayers is 
Table 5. Percentage of men and women per decile for Bilbao and Antwerp

\begin{tabular}{|c|c|c|c|}
\hline \multirow[b]{2}{*}{ Decile } & \multicolumn{3}{|c|}{ Bilbao } \\
\hline & $\begin{array}{l}\text { Amount range decile } \\
\text { (maravedis) }\end{array}$ & $\%$ of men per decile & $\%$ of women per decile \\
\hline 1 & $4-31$ & 30.3 & 58.7 \\
\hline 2 & $31-42$ & 18.8 & 74.5 \\
\hline 3 & $44-62$ & 62.5 & 24.0 \\
\hline 4 & $62-125$ & 54.3 & 27.9 \\
\hline 5 & $125-161$ & 79.8 & 9.6 \\
\hline 6 & $162-200$ & 81.2 & 4.8 \\
\hline 7 & $203-312$ & 70.0 & 6.8 \\
\hline 8 & $312-581$ & 76.8 & 4.3 \\
\hline 9 & $583-1250$ & 79.7 & 3.4 \\
\hline \multirow[t]{2}{*}{10} & $1250-16581$ & 83.1 & 0.5 \\
\hline & \multicolumn{3}{|c|}{ Antwerp } \\
\hline Decile & Amount range decile (shillings) & $\%$ of men per decile & $\%$ of women per decile \\
\hline 1 & $9-25$ & 72.8 & 25.6 \\
\hline 2 & $25-37$ & 82.4 & 17.6 \\
\hline 3 & $37-50$ & 86.3 & 13.7 \\
\hline 4 & $50-80$ & 92.7 & 7.3 \\
\hline 5 & $80-110$ & 91.1 & 8.1 \\
\hline 6 & $110-150$ & 92.7 & 7.3 \\
\hline 7 & $150-200$ & 93.5 & 5.6 \\
\hline 8 & $200-265$ & 87.9 & 11.3 \\
\hline 9 & $266-400$ & 91.9 & 8.1 \\
\hline 10 & $400-3200$ & 88.7 & 9.7 \\
\hline
\end{tabular}

Sources: See Tables 1 and 2.

lowest in the middle deciles (4-7) of the tax payment distribution for Antwerp in Figure $1{ }^{122}$ In Bilbao, the sources did not refer to women from middling groups, although such groups were undoubtedly present in the town. However, there appear to have been many more women in the lowest groups of taxpayers in Bilbao than in Antwerp. A greater number of women in Bilbao clearly could not fall back on the support of their nuclear family, possibly because Bilbao did not have institutions such as the guilds, nor was its economy based on household production. The tax registers support the same conclusion drawn from the analysis of the ordinances laying out 'what should happen' and the court cases which described 'what actually happened' in practice. Women in Bilbao were visible, economically active players, 

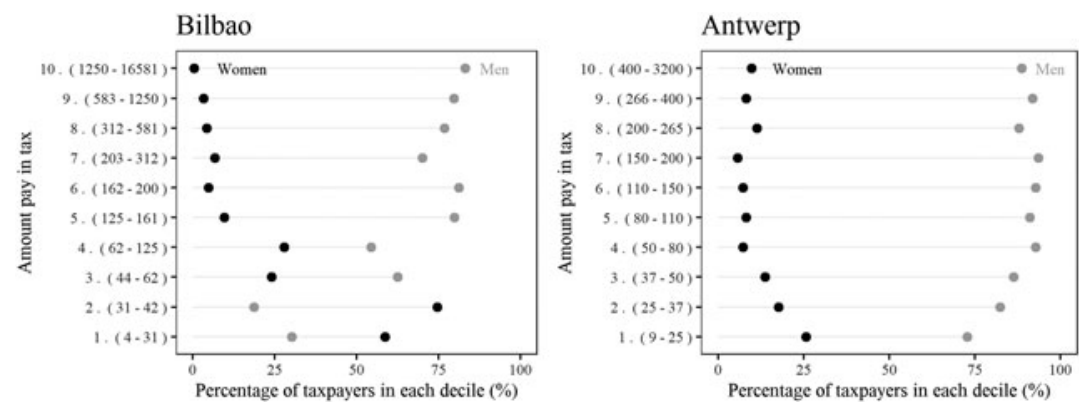

Figure 1. Deciles of taxpayers, by amount paid in tax, in the tax registers of Bilbao (1470) and Antwerp (1537 and 1552), showing the percentage of women and men in each decile. Amounts paid in Bilbao given in maravedis; amounts paid in Antwerp given in shillings.

Sources: Bilbao: Javier Enríquez Fernández, Concepción Hidalgo de Cisneros Amestoy, Araceli Lorente Ruigómez and Adela Martínez Lahidalga, Repartimientos y foguera-vecindario de Bilbao (1464-1492) (San Sebastián, 1996). Antwerp: City Archives of Antwerp, Antwerp (hereafter CAA), HN\#103, Belastingscohieren van 1537. Huizentelling: 4de en 6de wijk, buitenijen (PK 2559 en 2566), 1537; CAA, HN\#579, Afschriften uit RK 2387 en RK 2523, 1552.

whereas women's work in Antwerp was hidden behind the economic activities of their household as structured by the craft guilds. Nevertheless, the measurement of gender inequality in the two locations has demonstrated that although women in Bilbao had greater independent agency than their counterparts in Antwerp, this did not necessarily give them a superior financial position.

\section{Conclusion}

Traditionally the differences between northern and southern Europe in women's agency have been explained by comparing the legal systems and family structures of the two regions. The aim of this article has been to propose a new comparative approach by considering women's economic position in the northern commercial hub of Antwerp and the Castilian harbour town of Bilbao; comparing specific towns, rather than making generalisations about 'northern Europe' and 'southern Europe', and recognising that there were many factors other than legal systems which influenced women's agency. The craft guilds had a great impact on the labour opportunities of women in Antwerp; they offered them security, but limited their chances to work independently. Nevertheless, there were women working outside the craft guilds in Antwerp, in a similar way to Bilbao's licensed retailers. In both towns, however, the local government scrutinized and regulated the traders' activities, viewing them with suspicion. In Antwerp the craft guilds not only influenced what work women could do, they also dictated which groups of women, often defined by marital status, were permitted to do that work. In Bilbao, tradeswomen of all marital statuses were active in the local markets. While there was a larger disparity in income between tradeswomen and their male counterparts in Bilbao, women from the middling and higher classes of urban society are more evident in the sources from Antwerp.

In Bilbao, poorer tradeswomen were able to contest the regulations the town council imposed on their activities by working as a group. Women in Antwerp were more dependent on menfolk and their household when it came to opposing 
regulations or settling court cases. In both towns the nature of women's arguments and their chances of success changed when they took on the town council individually. Despite the regulations imposed on them, female workers in both towns frequently found ways to circumvent the restrictions: the town councils and the craft guilds clearly found it very difficult to stop women from making a living.

Acknowledgements. This article is part of the $\mathrm{PhD}$ research project 'Dismantling the borders. A comparative analysis of women's market activities in Brabant and Biscay, ca. 1420 - ca. 1550', funded by FWO - Research Foundation Flanders. I would like to thank Shennan Hutton, Susan Leonard, Eilidh Garrett, and the editorial board of Continuity and Change for their advice and language edits of this article. Furthermore, I thank the three anonymous reviewers for their insightful and constructive suggestions.

\section{Notes}

1 Jan Van Herwaarden, Opgelegde bedevaarten: een studie over de praktijk van opleggen van bedevaarten (met name in de stedelijke rechtspraak) in de Nederlanden gedurende de late middeleeuwen (ca. 1300 - ca. 1550) (Assen, 1978), 18-20; Ellen E. Kittell, 'Traveling for atonement: civilly imposed pilgrimages in medieval Flanders', Canadian Journal for Netherlandic Studies 31 (2010), 21-37.

2 F. Melis-Taemans, Correctieboeck 1414-1512 (Antwerpen, 1979), 125.

3 Anna Bellavitis, Women's work and rights in early modern urban Europe (Cham, 2018), 53; Claire Crowston, 'Women, gender, and guilds in Early Modern Europe: an overview of recent research', International Review of Social History 53, 16 (2008), 19-44, 29-37; Daryl Hafter, Women at work in preindustrial France (University Park, 2007), 291; Anne Montenach, 'Working at the margins. Women and illicit economic practices in Lyon in the late seventeenth and eighteenth centuries', in Merridee Bailey, Tania Colwell and Julie Hotchin eds., Women and work in premodern Europe (New York, 2018), 192213; Teresa Phipps, Medieval women and urban justice. Commerce, crime and community in England, 1300-1500 (Manchester, 2020).

4 Javier Enríquez Fernández, Concepción Hidalgo de Cisneros Amestoy, Araceli Lorente Ruigómez and Adela Martínez Lahidalga, Libro de acuerdos y decretos municipales de la villa de Bilbao (1509 y 1515) (San Sebastián, 1995), 87v.

5 Ernesto García Fernández, 'Las cofradías de oficios en el País Vasco durante la edad media (1350-1550)', Studia histórica. Historia medieval 15 (1997), 11-40, 27.

6 This has been demonstrated previously for early modern France: Hafter, Women at work in preindustrial France, 5. This article takes a different approach, however, and considers other geographical settings in a different chronological time frame.

7 Martha C. Howell, Women, production, and patriarchy in late medieval cities (London, 1986), 27-30; Bellavitis, Women's work and rights in early modern urban Europe, 31.

8 Darlene Abreu-Ferreira, 'A status of her own: women and family identities in seventeenth-century Aveiro, Portugal', Journal of Family History 34, 1 (2009), 3-24, 10.

9 This article defines 'free' work or informal work as work not organised by institutions recognised by local government. In Bilbao, where retail was never organised in an official institution, all small-scale trades were informal. However, trading 'informally' is not synonym for trading illicitly. Although no institution led their work, many of the female traders in Bilbao, as well as the second-hand dealers in Antwerp which this article will discuss, were licensed. They had asked and received permission from the town councils or related craft guilds to conduct their trade. Hafter, Women at work in preindustrial France, 13 and 29; Janna Coomans, 'Policing female food vendors in the late medieval Netherlands', Yearbook of Women's History 36 (2017), 97-113, 108; Cristina Ayuso Sánchez, 'El mundo laboral femenino en el País Vasco medieval', Sancho el sabio: Revista de cultura e investigación vasca 30 (2009), 115-36, 129.

10 David Herlihy and Christiane Klapisch-Zuber, Tuscans and their families. A study of the Florentine Catasto of 1427 (New Haven and London, 1985); Tine De Moor and Jan Luiten van Zanden, 'Girl power: the European marriage pattern and labour markets in the North Sea region in the late medieval and early modern period', The Economic History Review 63, 1 (2010), 1-33. 
11 Bellavitis, Women's work and rights in early modern urban Europe, 8; De Moor and van Zanden, 'Girl power', 8; Sheilagh Ogilvie, A bitter living: women, markets, and social capital in early modern Germany (Oxford, 2006), 344-5; Myriam Carlier, 'The household: an introduction', in Myriam Carlier and Tim Soens eds., The household in late medieval cities, Italy and northwestern Europe compared (Leuven and Apeldoorn, 2001), 1-11, 2-3.

12 Julie Marfany, 'Family and welfare in early modern Europe: a north-south comparison', in Chris Briggs, P. M. Kitson and S. J. Thompson eds. Population, welfare and economic change in Britain, c.1270-1834: historical studies (Woodbridge, 2014), 103-27, 103; R. M. Smith, 'Les Toscans et leurs familles: Une étude du catasto florentin de 1427: David Herlihy and Christiane Klapisch-Zuber (Book Review)', Journal of Family History 6, 1 (1981), 107-28, 108.

13 Ogilvie, A bitter living, 344-5.

14 Ellen E. Kittell, 'Testaments of two cities: a comparative analysis of the wills of medieval Genoa and Douai', European Review of History 5, 1 (1998), 47-82, 47; Marfany, 'Family and welfare in early modern Europe', 103.

15 Anna Bellavitis and Beatrice Zucca Micheletto, 'Introduction: North versus South - gender, law and economic well-being in Europe in the fifteenth to nineteenth centuries', Anna Bellavitis and Beatrice Zucca Micheletto eds., Gender, law and economic well-being in Europe from the fifteenth to the nineteenth centuries (London, 2019), 1-27, 2.

16 Kittell, 'Testaments of two cities', 48.

17 Beatrice Zucca Micheletto, 'Reconsidering the southern Europe model: dowry, women's work and marriage patterns in pre-industrial urban Italy (Turin, second half of the $18^{\text {th }}$ century)', The History of the Family 16, 4 (2011), 354-70, 366-8.

18 Kittell, 'Testaments of two cities', 4-47; Marfany, 'Family and welfare in early modern Europe', 104.

19 Kittell, 'Testaments of two cities', 47-8.

20 Bellavitis and Zucca Micheletto, 'Introduction: North versus South', 1-2; Laura Van Aert, 'The legal possibilities of Antwerp widows in the late sixteenth century', The History of the Family 12, 4 (2007), 282-95, 285.

21 Dana Wessell Lightfood, Women, dowries and agency: marriage in fifteenth-century Valencia (Manchester, 2013), 1-3.

22 Guido Marnef, Antwerpen in de tijd van de Reformatie. Ondergrond protestantisme in een handelsmetropool 1550-1577 (Amsterdam and Antwerp, 1996), 36-41.

23 José Ignacio Salazar, 'Gobierno local en el Bilbao bajomedieval', Bidebarrieta, 12 (2003), 183-97.

24 See: Sherry B. Ortner, 'Specifying agency. The Comaroffs and their critics', Interventions 3, 1 (2001), 76-84, 78.

25 Jeroen Puttevils, “Eating the bread out of their mouth": Antwerp's export trade and generalized institutions, 1544-5', Economic History Review 68, 4 (2015), 1339-64.

26 Bert De Munck, Guilds, labour and the urban body politic: fabricating community in the Southern Netherlands, 1300-1800 (London and New York, 2018), 154-5.

27 Jose Angel García de Córtazar, Beatriz Arizaga Bolumburu, María Luz Rios Rodriguez, and Isabel del Val Valdivieso, Bizcaya en la edad media (San Sebastián, 1985), 274-8.

28 Ibidem, 283; Sergio Martínez Martínez, 'Desarrollo urbano de Bilbao en la edad media', in Beatriz Arizaga Bolumburu and Jesús Ángel Solórzano Telechea eds., Ciudades y villas portuarias del Atlántico en la edad media (Logroño, 2004), 115-46, 143-4.

29 García Fernández, 'Las cofradías de oficios en el País Vasco durante la edad media (1350-1550)', 16.

30 García de Córtazar, Arizaga Bolumburu, Rios Rodriguez and del Val Valdivieso, Bizcaya en la edad media, 308-12; Gregorio Monreal Zia, The Old Law of Bizkaia (1452). Introductory study and critical edition (Nevada, 2005), 67-8.

31 De Munck, Guilds, labour and the urban body politic, 205.

32 Estanislao Jaime Labayru y Goicoechea, Historia General de Bizcaya (Bilbao, 1968), appendix 27, 82040.

33 Ellen Burm and Bert De Munck, 'Het broodje gebakken? Huwelijksstrategieën en partnerkeuze van bakkers(kinderen) te Brussel in de overgang van het Ancien Régime naar de negentiende eeuw', Stadsgeschiedenis 5, 2 (2010), 148-68, 163.

34 City Archives of Antwerp, Antwerp (hereafter CAA), PK\#913, Gebodboek Abis 1439-1496, f. 68r-68v, 17 November 1481. 
35 CAA, PK\#915, Gebodboek 1539-1564 B, f. 68v-96r, 16 August 1546.

36 Brecht Dewilde and Johan Poukens, 'Bread provisioning and retail dynamics in the southern Low Countries: the bakers of Leuven, 1600-1800', Continuity and Change 26, 3 (2011), 405-38, 408.

37 Peter Stabel, 'From the market to the shop: retail and urban space in late medieval Bruges', in Bruno Blondé, Peter Stabel, Jon Stobart and Ilja Van Damme eds., Buyers and sellers. Retail circuits and practices in medieval and early modern Europe (Turnhout, 2006), 79-108, 101-2.

38 María Isabel del Val Valdivieso, 'El trabajo de las mujeres en el Bilbao tardomedieval', Formazio Koadernoak, 24 (1997), 65-92, 70.

39 Shennan Hutton, 'Women, men, and markets: the gendering of market space in late medieval Ghent', in Albrecht Classen ed., Urban space in the Middle Ages and Early Modern Age (Berlin, 2009), 409-32; Javier Enríquez Fernández, Concepción Hidalgo de Cisneros Amestoy, Araceli Lorente Ruigómez and Adela Martínez Lahidalga, Ordenanzas municipales de Bilbao (1477-1520) (San Sebastián, 1995), 17r-17v, 11 January 1482.

40 City Archives of Mechelen, Mechelen (hereafter CAM), Magistraat (Ordonnantiën) - Serie III, nr.2, Novum Chaos 2, f. 144r-147r; Ibidem, f. 243r-244v, 27 November 1520.

41 Stabel, 'From the market to the shop', 102, Bellavitis, Women's work and rights in early modern urban Europe, 53.

42 Ellen E. Kittell and Kurt Queller, "Whether man or woman": gender inclusivity in the town ordinances of medieval Douai', The Journal of Medieval and Early Modern Studies 30, 1 (2000), 63-100, 65.

43 Peter Stabel, 'Women at the market. Gender and retails in the towns of late medieval Flanders', in Wim Blockmans, Marc Boone en Thérèse de Hemptinne eds., Secretum Scriptorum: Liber alumnorum Walter Prevenier (Leuven and Apeldoorn, 1999), 259-76, 267.

44 Most of the registers containing economic conflicts used throughout this article are published in the Antwerpsch Archievenblad.

45 Javier Enríquez Fernández, Concepción Hidalgo de Cisneros Amestoy, Araceli Lorente Ruigómez and Adela Martínez Lahidalga, Repartimientos y foguera-vecindario de Bilbao (1464-1492) (San Sebastián, 1996); CAA, HN\#103, Belastingscohieren van 1537. Huizentelling: 4de en 6de wijk, buitenijen (PK 2559 en 2566), 1537; CAA, HN\#579, Afschriften uit RK 2387 en RK 2523, 1552.

46 Kittell and Queller, 'Whether man or woman', 65.

47 Coomans, 'Policing female food vendors in the late medieval Netherlands', 103.

48 Howell, Women, production, and patriarchy in late medieval cities, 9-21.

49 Kristien Harmsen and Helene Hubers, “En zij verkocht de vis ...". Visverkoopsters in Utrecht en Antwerpen van de veertiende tot en met de zeventiende eeuw', Dinamiek 8, 2 (1991), 29-40, 33; Coomans, 'Policing female food vendors in the late medieval Netherlands', 103.

50 Danielle Van den Heuvel, 'The multiple identities of early modern Dutch fishwives', Signs: Journal of Women in Culture and Society 37, 3 (2012), 587-94, 588-92; Kittell, 'Testaments of two cities', 79.

51 It is not entirely clear whether the gardeners' guild was referring to married women who were full members of the guild, or the wives of gardeners who helped their husbands in their work and therefore were considered as belonging within the guild structure.

52 'Behoudelic als van den dochteren van den hoveniers nae de doot van vader ende moeder blivende.' CAA, GA\#4001, Ambachtenboeck 1430-1561, f. 64v, 30 July 1492.

53 Burm and De Munck, 'Het broodje gebakken?', 153; Martha C. Howell, 'Achieving the guild effect without guilds: crafts and craftsmen in late medieval Douai', in Pascale Lambrechts and Jean-Pierre Sosson eds., Les métiers au Moyen Age (Louvain-la-Neuve, 1994), 109-28, 126-7.

54 ' $[. .$.$] dat eenyegelyc meester alsoe vele leercnapen ende vrouwen instellen sal moegen als hem dat$ gelieft, $[\ldots]$ noch anders en doen dan dat zy deselve hantschoene oft tesschen naeyen ende stofferen, dwelke vrouwenwerc is ende vrouwen betaemt te doene [...]'. Pierre Génard, 'Het 'Register vanden dachvaerden' (vervolg)', Antwerpsch Archievenblad 20 (1883), 1-472, 400-1.

$55 \mathrm{Ibidem}$. The glove and pursemakers guild of Antwerp was not alone, as a similar conflict arose in Leuven, another town in Brabant, around the same time. See: Nena Vandeweerdt, De Leuvense ambachtenwereld - een mannenwereld?, Claves Scabinorum, 9 (Leuven, 2017), 7-8.

56 Maryanne Kowaleski and Judith M. Bennett, 'Crafts, gilds, and women in the Middle Ages: fifty years after Marian K. Dale', Signs: Journal of Women in Culture and Society 14, 2 (1989), 475-501, 480; Eline Van Onacker and Hadewijch Masure, 'Unity in diversity. Rural poor relief in the sixteenth-century Southern Low Countries', TSEG. Low Countries Journal of Social and Economic History, 12, 4 (2015), 59-88, 70 - 
1. As earlier studies have shown, Antwerp's household-based economy led to a strong, profitable position for some widows who took over as head of their household and the family production unit. See: Van Aert, 'The legal possibilities of Antwerp widows in the late sixteenth century', 288; Marianne Danneel, Weduwen en wezen in het laat-middeleeuwse Gent (Leuven-Appeldoorn, 1995).

57 De Moor and van Zanden, 'Girl power'; Marfany, 'Family and welfare in early modern Europe', 106108; Katrina Honeyman and Jordan Goodman, 'Women's work, gender conflict, and labour markets in Europe, 1500-1900', The Economic History Review 44, 4 (1991), 608-28, 610.

58 María Isabel Del Val Valdivieso, 'La solaridad familiar en Vizcaya en el siglo XV', Vizcaya en la Edad Media (Congreso de Estudios históricos Vizcaya en la Edad Media, Bilbao, 1984), 333-7, 336; Gregorio Monreal Zia, The Old Law of Bizkaia (1452). Introductory study and critical edition (Reno, 2005); José Ángel García de Cortázar, Beatriz Arízaga Bolumburu, María Luz Ríos Rodríguez and María Isabel del Val Valdivieso, Vizcaya en la edad media: evolución demográfica, económica, social y política de la comunidad vizcaína medieval, Volume 3 (4 volumes) (San Sebastian, 1985), 240.

59 One had no marital status listed, and the other was probably still a young woman as she also worked as a servant.

60 Enríquez Fernández, de Cisneros Amestoy, Lorente Ruigómez and Martínez Lahidalga, Ordenanzas municipales de Bilbao, 276r-279r, 2 October 1510.

61 The women appearing before the council were listed as: 'Mari Peres de Bermeo, Elvira de Gaxmuri; fishmongers, Joana de Gaxmuri, Mari Saes de Basoçabala, Mari Saes de Maruri, Joana de Larrea, Mari Saes de Agüero, Mari Saes de Susunaga, Mari Peres de Çurvaran, Catelina de Bedia, Toda de Avando, Catalina de Otannes, Sancha de Anunçibay, Teresa de Galdames, Mari Fernandes de Salzedo, Teresa de Musquis, Mari Martines de Mendieta; sardine sellers, Catalina de Navarra; fishmonger....Mayora de Iturribalçaga, another sardine seller, was ill and therefore did not come.' Enríquez Fernández, de Cisneros Amestoy, Lorente Ruigómez and Martínez Lahidalga, Ordenanzas municipales de Bilbao, 276r-279r, 2 October 1510.

62 Darlene Abreu-Ferreira, 'Neighbours and Traders in a Seventeenth-Century Port Town', Signs: Journal of Women in Culture and Society 37, 3 (2012), 581-7, 582.

63 Archivo de la Real Chancilleria de Valladolid, Valladolid (hereafter ARCHV), Registro de ejecutorias, 273,12, 21 April 1512.

64 Archivo Foral de Bizkaia, Bilbao Antigua 0304/001/011, 1532.

65 Hafter, Women at work in preindustrial France, 192; Bart Lambert, 'Merchants on the margins: fifteenth-century Bruges and the informal market', Journal of Medieval History 42, 2 (2016), 226-53, 238-9, Howell, Women, production, and patriarchy in late medieval cities, 84.

66 A literal translation would be 'female out-carrier', given the meaning of the word, however, the closest translation would be 'female second-hand dealer. Further on, I simply refer to them as 'uitdraagsters'.

67 CAA, GA\#4001, Ambachtenboeck 1430-1561, f. 30r-32r, 10 November 1436.

68 CAA, GA\#4277, Oudekleerkopers.

69 CAA, PK\#915, Gebodboek 1539-1564 B, f. 58r, 16 August 1544.

70 An ordinance from the neighboring town Mechelen states that 'uitdraagsters' in that town were given goods to sell by citizens and other inhabitants and traders. The 'uitdraagsters' received a set payment for the goods they sold and had to give the income of the sales to the previous owners. CAM, A.5-A.5.1-0653-I-A-1, 1r-29v, 16 December 1577.

71 Merry Wiesner Wood, 'Paltry peddlers or essential merchants? Women in the distributive trades in early modern Nuremberg', The Sixteenth Century Journal 12, 2 (1981), 3-13; Isabella H. van Eeghen, 'Uitdraagsters 't zij man of vrouw', Maandblad Amstelodamum 56, (1969), 102-10.

72 CAA, GA\#4273, Oudekleerkopers. Privilegieboek, f. 7v-13v, 19 January 1550.

73 Ordinances about the second-hand dealers were made in: 1429, 1433, 1435, 1436, 1485, 1505, 1527, 1537, 1544, 1547, 1550, 1551, and 1556.

74 'Item, dat van nu voirdane gheenen uuytdraechster voervenster houden en sal op te peyne van tween ouden schilden te verbueuren te bekeeren in drijen als voerscreven is.' CAA, GA\#4275, f. $85 \mathrm{r}-88 \mathrm{v}, 10$ November 1436.

75 In the Low Countries, these were the very trades that the craft guilds tried to monopolize. See: Stabel, 'From the market to the shop', 104.

76 Darlene Abreu-Ferreira, 'Fishmongers and shipowners: women in maritime communities of Early Modern Portugal', The Sixteenth Century Journal 31, 1 (2000), 7-23, 7-8. 
77 One such widow was Isabel de Sabugal, a citizen of Portugalete, a town near Bilbao. She got into a dispute with a Gallician trader over five millares and twelve barrels of sardines that she wanted to buy from him. Isabel was clearly a substantial merchant. See: Archivo de la Real Chancillería de Valladolid, Valladolid (hereafter ARCHV), Sala de Vizcaya, 79,1, 1552; Ayuso Sánchez, 'El mundo laboral femenino en el País Vasco medieval', 125-6.

78 The new estimators had to judge the quality of the fish and weigh it. The weight was important, as it was related to the price that fishmongers could ask for. Enríquez Fernández, de Cisneros Amestoy, Lorente Ruigómez and Martínez Lahidalga, Ordenanzas municipales de Bilbao (1477-1520), 143v-144r, 20 December 1512 .

79 Judith M. Bennett, Ale, beer, and brewsters in England. Women's work in a changing world, 1300-1600 (New York and Oxford, 1996), 145-7; Ogilvie, A bitter living, 8.

80 García de Cortázar, Arízaga Bolumburu, Ríos Rodríguez and del Val Valdivieso, Vizcaya en la edad media, 329-31 and 332; Rosa Iziz and Ana Iziz, Historia de Las Mujeres En Euskal Herria. 1. Prehistoria, Romanización y Reino de Navarra (Tafalla, 2016), 258.

81 Danielle van den Heuvel, 'Selling in the shadows: peddlers and hawkers in early modern Europe', in Marcel van der Linden and Leo Lucassen eds., Working on labor. Essays in honor of Jan Lucassen (Leiden, 2012), 125-51, 129.

82 Enríquez Fernández, de Cisneros Amestoy, Lorente Ruigómez and Martínez Lahidalga, Libro de acuerdos $y$ decretos, 87r-87v, 14 November 1509.

83 Enríquez Fernández, de Cisneros Amestoy, Lorente Ruigómez and Martínez Lahidalga, Ordenanzas municipales de Bilbao, f. 273v-274v, 18 September 1510.

84 Ibidem, f. 276r-279r, 2 October 1510.

85 Wiesner Wood, 'Paltry peddlers or essential merchants?', 8-9.

86 Van den Heuvel, 'The multiple identities of early modern Dutch fishwives', 588; Ben Eersels, 'The craft guilds are the city. Political participation in late medieval towns Brabant and Liège (c. 1360-1500)', (Unpublished D. Phil. thesis, KU Leuven, 2018).

87 Crowston, 'Women, gender, and guilds in Early Modern Europe', 37.

88 Hutton offers an example from fourteenth-century Ghent, but even in Leuven, one of the main towns of Brabant, women rarely had direct influence on economic regulation. Hutton, 'Women, men, and markets', 414; Nena Vandeweerdt, "Van den vleeschouweren oft pensvrouwen." De economische mogelijkheden voor vrouwen in het Leuvense vleeshouwersambacht in de vijftiende en zestiende eeuw', TSEG. Low Countries Journal of Social and Economic History 15, 1 (2018), 5-30.

89 City Archives of Leuven, Leuven (hereafter CAL), CAL, 1523, f. 155r - 156r, 23 May 1424.

90 Eersels, 'The craft guilds are the city', Crowston, 'Women, gender, and guilds in Early Modern Europe', 24; Hafter, Women at work in preindustrial France, 23.

91 Martha C. Howell, 'The spaces of late medieval urbanity', in Peter Stabel and Marc Boone eds., Shaping urban identity in late medieval Europe (Leuven, 2000), 3-23, 7-8; Carol Symes, 'Out in the open, in arras: sightlines, soundscapes, and the shaping of a medieval public sphere', in Caroline Goodson, Anne E. Lester and Carol Symes eds., Cities, texts and social networks: 400-1500. Experiences and perceptions of medieval urban space (Surrey and Burlington, 2010), 279-302, 302.

92 CAA, PK\#913, Gebodboek Abis 1439-1496, f. 80v, 17 August 1485.

93 '[...] dat van nu voortane egheene uuytdraechsters, oude cleercoopers, cleerlappers oft andere persoonen wye die sijn $[\ldots]$ in den viorscreven huydevetters, corte oft langhe gasthuisstraten, noch oick andere plaetsen binnen deser stadt, meer en selen moegen voortstaen, voortdoen, noch aldaer ter venteren dragen [...].' CAA, PK\#915, Gebodboek 1539-1564 B, f. 58r, 16 August 1544.

94 Ibid.

95 Enríquez Fernández, Hidalgo de Cisneros Amestoy, Lorente Ruigómez and Martínez Lahidalga, Ordenanzas municipales de Bilbao, 143v-144r, 2 October 1510.

96 Enríquez Fernández, Hidalgo de Cisneros Amestoy, Lorente Ruigómez and Martínez Lahidalga, Libro de acuerdos y decretos municipales, 24r; Ayuso Sánchez, 'El mundo laboral femenino en el País Vasco medieval', 130.

97 There is no accurate translation for this premodern occupation. 'Packer' or 'carrier' is an approximate translation, but does not describe the work these women were doing, which was guarding goods and receiving payment from the buyers. 
98 García de Cortázar, Arízaga Bolumburu, Ríos Rodríguez and del Val Valdivieso, Vizcaya en la edad media, 329-31.

99 ' [...] e aun si algunas abian sido fasta allí aquello abia seido a voluntad del dicho concejo e regimiento [...]'. ARCHV, Sala de Vizcaya, 3467,5, 1536.

100 Ibid.

101 Bellavitis, Women's work and rights in early modern urban Europe, 53.

102 Coomans, 'Policing female food vendors in the late medieval Netherlands', 104; Van Aert, 'The legal possibilities of Antwerp widows in the late sixteenth century', 283.

103 Vandeweerdt, 'Van den vleeschouweren oft pensvrouwen.', 18.

104 L. Bisschops, 'Oudt Register, mette Berderen, 1336-1439 (vervolg)', Antwerpsch Archievenblad 29 (1892), 1-262, 3-4.

105 Stabel, 'Women at the market', 273.

106 Ibidem.

107 Enríquez Fernández, Hidalgo de Cisneros Amestoy, Lorente Ruigómez and Martínez Lahidalga, Libro de acuerdos $y$ decretos municipales, $16 \mathrm{v}$.

108 Idem, 19r. Bart Lambert and Anna Montenach also noted the use of poverty as an argument by informal traders in Lyon and Bruges. See: Lambert, 'Merchants on the margins', 237; Montenach, 'Working at the margins', 203.

109 M. del Pilar Rabade Obrado, 'La mujer trabajadora en los ordenamientos de Cortes, 1258-1505', in Cristina Segura Graíno and Angela Muñoz Fernández eds., El trabajo de las mujeres en la Edad Media hispana (Madrid, 1988), 113-40, 126-27.

110 Ana María Rivera Medina, “E tobimos por bien echar sisa”. Los impuestos al consumo como media de financiación concejil. Bilbao, 1300-1550', in Jesús Ángel Solórzano Telechea and Beatriz Arizaga Bolumburu eds., La gobernanza de la ciudad europea en la edad media (Logroño, 2011), 427-43, 43643; Michael Limberger, 'The making of the urban fiscal system of Antwerp until 1800: excises, annuities and debt management', in José Ignacio Andrés Ucendo and Michael Limberger eds., Taxation and debt in the early modern city (London, 2012), 131-48, 140.

111 Enríquez Fernández, de Cisneros Amestoy, Lorente Ruigómez and Martínez Lahidalga, Repartimientos y foguera-vecindario de Bilbao (1464-1492).

112 Van Aert, 'The legal possibilities of Antwerp widows in the late sixteenth century', 284.

113 Laura Van Aert states the same for Antwerp widows: A widow's previous marriage could be a source of empowerment and provide her with greater financial awareness and expectations, which influenced her decision as to whether to remarry. The widow brought with her into a second or later marriage a wealth of financial and legal experience, which was reflected in the new marriage contract. In: Van Aert, 'The legal possibilities of Antwerp widows in the late sixteenth century', 288; Danneel, Weduwen en wezen in het laatmiddeleeuwse Gent, 404-6.

114 Bellavitis, Women's work and rights in early modern urban Europe, 32.

115 Mireia Comas-Via, 'Widowhood and economic difficulties in medieval Barcelona', Historical Reflections/Réflexions Historiques 43, 1 (2017), 93-103, 94.

116 Janire Castrillo Casado, 'Participación de las mujeres en la economía urbana del País Vasco durante la Baja Edad Media’, in María Isabel del Val Valdivieso and Juan Francisco Jiménez Alcázar eds., Las mujeres en la Edad Media (Murcia-Lorca, 2013), 213-22, 214.

117 Comas-Via, 'Widowhood and economic difficulties in medieval Barcelona'.

118 Enríquez Fernández, de Cisneros Amestoy, Lorente Ruigómez and Martínez Lahidalga, Repartimientos y foguera-vecindario de Bilbao (1464-1492).

119 Ayuso Sánchez, 'El mundo laboral femenino en el País Vasco medieval', 117; María Isabel del Val Valdivieso, 'Los espacios del trabajo demenino en la Castilla del siglo XV', Studia histórica. Historia medieval 26 (2008), 63-90, 89.

120 Bert De Munck, 'De return of ouderwetse debatten? Recente trends in het onderzoek naar ambachtsgilden', Leidschrift | Historisch Tijdschrift 25, 2 (2013), 73-95; Steven E. Epstein, 'Craft guilds in the premodern economy: a discussion', The Economic History Review 61, 1 (2008), 155-74; Sheilagh Ogilvie, 'Rehabilitating the guilds: a reply', The Economic History Review 61, 1 (2008), 175-82; Sheilagh Ogilvie, "Whatever is, is right"? Economic institutions in pre-industrial Europe', The Economic History Review 60, 4 (2007), 649-84; Hafter, Women at Work in Preindustrial France.

121 De Moor en van Zanden, 'Girl power'; Sheilagh Ogilvie, 'Whatever is, is right?. 
122 Although there was undoubtedly a pronounced hierarchy amongst craftsmen, their middling status in urban society is generally accepted. De Munck, Guilds, labour and the urban body politic, 237-41.

\section{French Abstract}

Dans cet article, l'auteur compare les perspectives de travail pour les femmes de Bilbao, alors en Castille septentrionale, et celles d'Anvers, aux Pays-Bas, de 1400 à 1560. Elle soutient que l'organisation du travail était fort différente dans les deux villes, les femmes n'ayant pas de ce fait les mêmes opportunités d'emploi. Alors qu'à Anvers, les femmes travaillaient souvent aux côtés d'autres membres de leur foyer en raison des corporations d'artisans qui dominaient l'économie urbaine, à Bilbao, nombre de métiers informels étaient ouverts aux femmes elles-mêmes, indépendamment de leur mari ou d'un autre parent masculin. En conséquence, les femmes de Bilbao sont plus visibles dans les sources et ont pu exercer plus d'influence sur le conseil municipal.

\section{German Abstract}

In diesem Beitrag vergleiche ich die Arbeitsmöglichkeiten von Frauen in Bilbao (nördliches Kastilien) und Antwerpen (Niederlande) von 1400 bis 1560 und behaupte, dass die unterschiedliche Arbeitsorganisation in den beiden Städten die wirtschaftlichen Chancen von Frauen stark beeinflusste. Während Frauen in Antwerpen wegen der in der Stadt vorherrschenden Handwerkerzünfte häufig neben anderen Mitgliedern ihres Haushaltes arbeiteten, waren in Bilbao die informellen Handwerke auch für die Frauen selbst offen, unabhängig von ihrem Ehemann oder einem anderen männlichen Verwandten. Infolgedessen sind Frauen in Balbao viel stärker in den Quellen sichtbar und konnten auch mehr Einfluss auf den Stadtrat nehmen. 